\title{
Antioxidant Properties of the Leaves of Chromolaena odorata Linn
}

\section{Bhargava D, Mondal C K, Shivapuri J N, Mondal S, Kar S}

National Medical College and Teaching Hospital, Birgunj, Parsa, Nepal; Vidyasagar University, Midnapore, West Bengal, India, Department of Botany, Midnapore College, Midnapore, West Bengal, India.

Correspondence address: Dipak Bhargava, National Medical College and Teaching Hospital, Birgunj, Parsa, Nepal;

Email:db_mid@yahoo.co.in

\begin{abstract}
Introduction: Chromolaena odorata Linn (Asteraceae) locally known as "Banmara" has the reputation of being used as a medicinal herb in Nepal. A systemic search for drug research in now considered to be a rational approach. Therefore in the present study an effort has been made to evaluate the antioxidant activity of the leaves of the above mentioned plant.

Methods: In the present research work the ethanolic and methanolic extract of leaves of the plant C. odorata Linn was assessed for free radical scavenging and antioxidant activity. In this work the ability of the extract to scavenge nitric oxide, hydroxyl radical and 1,1-diphenyl-2picrylhydrazyl $^{1}(\mathrm{DPPH})$ were used to assess its free radical scavenging potentials.

Results: The DPPH radical inhibition (\%) was 59.10, 52.13 and 81.12 for ethanolic extract, methanolic extract and ascorbic acid respectively. Similarly ethanolic and methanolic extract also showed significant free radical scavenging action against nitric oxide and hydroxyl radical.

Conclusion: Against the backdrop of many known medicinal properties of this plant its ethanolic and methanolic extract of leaves reveals significant antioxidant properties.
\end{abstract}

Key words: Chromolaena odorata, Extraction, Antioxidant properties

\section{Introduction}

Chromolaena odorata (L). R.M. King and H. Robinson (synonym: Eupatorium odoratum L.) is known to have originated from South and Central America and is commonly called siam weed, bitter bush or jack in the bush $^{1 \cdot}$ It is an herbaceous perennial that grows to a height of three meters in open situation and up to eight meters when assumed a scrambling habitat in the interior forests. ${ }^{2}$

C. odorata (L) has the reputation of using as a medicinal herb for a variety of ailments including malaria, fever, and the aqueous leaf extract of the plant is used as antiseptic. The fresh leaves and extract of C. odorata (L). are used in traditional herbal treatment in developing countries for burns, soft tissue wounds and skin infections. ${ }^{3}$ In folk medicine, a decoction of the leaf is used as a cough remedy. The literature reveals that the leaves of $\mathrm{C}$. odorata
(L). are also used against sexually transmitted diseases. Trolox equivalent antioxidant capacity and ferric-reducing antioxidant capacity power assays showed that the antioxidant activities were strongly correlated with total phenols. ${ }^{4}$ In this work the leaves of C. odorata Linn were extracted using ethanol and methanol. However, reports on antioxidant activity of C. odorata Linn was very scarce. Therefore in the present study an effort has been made to analyse the free radical scavenging activity of the leaves of C. odorata Linn.

\section{Methods}

Plant material: The leaves of C. odorata (L) collected from road sides through the different areas of Parsa (Birgunj), Bara (Simra) and Makwanpur (Hetauda) districts (altitude 
about $1500 \mathrm{ft}$ from above the sea level), and processed at Clinical Microbiology and Biochemistry laboratory of National Medical College and Teaching Hospital, Birgunj, Nepal. These plants were identified on the basis of ethnobotanical knowledge of the particular area, available literatures, ${ }^{5,6}$ and in the Department of Botany, Vidyasagar University, India.

Extraction of the leaves of C. odorata Linn: The dried leaf powder $(200 \mathrm{~g})$ was extracted with various solvents namely methnol and ethanol in a soxhlet apparatus. The solvents were then evaporated to dryness under reduced pressure which will give a greenish coloured sticky residue. The extracts were then subjected to antioxidant activity studies. Antioxidant activity of the leaves of C. odorata Linn

Scavenging of DPPH radical ${ }^{7,8}$

This assay depends on the measurement of the scavenging ability of the antioxidant test substances towards the stable radical. The free radical scavenging activity ${ }^{7}$ of the extracts (EOA and EOM) was examined in vitro using DPPH radical. The test extracts were treated with different concentrations from a maximum of $300 \mathrm{~g} / \mathrm{ml}$ to minimum of $5 \mathrm{~g} / \mathrm{ml}$. The reaction mixture consisted of $1 \mathrm{ml}$ of $0.1 \mathrm{mM}$ DPPH in ethanol, $0.95 \mathrm{ml}$ of $0.05 \mathrm{M}$ Tris- $\mathrm{HCl}$ buffer ( $\mathrm{pH} 7.4), 1$ $\mathrm{ml}$ of ethanol and $0.05 \mathrm{ml}$ of the extract. The absorbance of the mixture was measured at $517 \mathrm{~nm}$ exactly $30 \mathrm{sec}$ after adding the extract. The experiment was performed in triplicate and the $\%$ of scavenging activity was calculated using the formula; 100- [100/blank absorbance $\times$ sample absorbance]

\section{Scavenging of nitric oxide ${ }^{9,10}$}

Sodium nitroprusside $(5 \mathrm{M})$ in standard phosphate buffer solution was incubated with different concentration of the test extracts dissolved in standard phosphate buffer (0.025M, pH 7.4) and the tubes were incubated at $25 \mathrm{C}$ for $5 \mathrm{hrs}$. After $5 \mathrm{~h}, 0.5 \mathrm{ml}$ of incubated solution was removed and diluted with $0.5 \mathrm{ml}$ Griess reagent (prepared by mixing equal volume of $1 \%$ sulphanilamide in $2 \%$ phosphoric acid and $0.1 \%$ naphthylethylene diamine dihydrochloride in water). The absorbance of the chromophore formed was measured at $546 \mathrm{~nm}$. The control was also carried out in similar manner using distilled water instead of extracts. The experiment was performed in triplicate and \% scavenging activity was calculated using the formula; 100- [100/blank absorbance $\times$ sample absorbance]

The activity was compared with ascorbic acid, which was considered as standard antioxidant.

Hydroxyl radical scavenging activity ${ }^{11}$
The hydroxyl radical scavenging activity was measured by studying the competition between deoxyribose and the extract for hydroxyl radicals generated from the $\mathrm{Fe} 3+/$ ascorbate/EDTA/H2O2 system. The reaction mixture contained deoxyribose (2-8mM), $\mathrm{FeCl} 3(0.1 \mathrm{mM})$, EDTA $(0.1 \mathrm{mM})$, ascorbate $(0.1 \mathrm{mM}), \mathrm{H} 2 \mathrm{O} 2(1 \mathrm{mM}), \mathrm{KH} 2 \mathrm{PO} 4-$ $\mathrm{KOH}$ buffer $(20 \mathrm{mM}, \mathrm{pH} 7.4)$ and various concentrations $(25-400 \mu \mathrm{g} / \mathrm{ml}$ of extracts and standard 10-80 $\mu \mathrm{g} / \mathrm{ml})$ of standard drug in a final volume of $1 \mathrm{ml}$. The reaction mixture was incubated for $1 \mathrm{hr}$ at $37^{\circ} \mathrm{C}$; deoxyribose degradation was measured at $532 \mathrm{~nm}$.

\section{Statistical analysis}

All the experiment was carried out for three times and the values were represented as the mean Standard Deviation $(\mathrm{SD})(\mathrm{n}=5)$. For determining the statistical significance, standard error mean and analysis of variance (ANOVA) at $5 \%$ level significance was employed. The $\mathrm{P}$ values $<0.05$ were considered as significant ${ }^{12}$.

\section{Results}

DPPH scavenging: The ethanolic (EOA) and methanolic extracts (EOM) of the leaves of C. Odorata Linn exhibits free radical scavenging effect of DPPH in a concentration dependent manner upto a concentration of $300 \mu \mathrm{g} / \mathrm{ml}$. The EOA showed more scavenging activity than EOM. The reference standard ascorbic acid shows a significant radical scavenging potential in the concentration of $1 \mu \mathrm{g} / \mathrm{ml}$. The DPPH radical inhibition (\%) was 59.10, 52.13 and 81.12 for EOA, EOM and ascorbic acid respectively in table 1 . 
Table 1: Free radical scavenging activity of C. odorata Linn leaves extracts by DPPH

\begin{tabular}{|c|c|c|c|c|c|c|c|}
\hline \multirow{2}{*}{ Drugs } & \multicolumn{7}{|c|}{$\%$ Scavenging (Mean \pm SEM) of triplicates } \\
\hline & $5 \mu \mathrm{g} / \mathrm{ml}$ & $10 \mu \mathrm{g} / \mathrm{ml}$ & $20 \mu \mathrm{g} / \mathrm{ml}$ & $40 \mu \mathrm{g} / \mathrm{ml}$ & $80 \mu \mathrm{g} / \mathrm{ml}$ & $160 \mu \mathrm{g} / \mathrm{ml}$ & $300 \mu \mathrm{g} / \mathrm{ml}$ \\
\hline $\mathrm{EOA}^{*}$ & $24.56 \pm 0.002$ & $26.56 \pm 0.001$ & $34.72 \pm 0.001$ & $41.40 \pm 0.001$ & $49.23 \pm 0.001$ & $55.11 \pm 0.002$ & $59.10 \pm 0.002$ \\
\hline $\mathrm{EOM}^{* *}$ & $22.54 \pm 0.002$ & $24.86 \pm 0.002$ & $27.85 \pm 0.001$ & $32.30 \pm 0.001$ & $41.44 \pm 0.002$ & $42.05 \pm 0.002$ & $52.13 \pm 0.002$ \\
\hline \multirow[t]{2}{*}{ Vit C } & $0.1 \mu \mathrm{g} / \mathrm{ml}$ & $0.2 \mu \mathrm{g} / \mathrm{ml}$ & $0.4 \mu \mathrm{g} / \mathrm{ml}$ & $0.6 \mu \mathrm{g} / \mathrm{ml}$ & $0.8 \mu \mathrm{g} / \mathrm{ml}$ & $1 \mu \mathrm{g} / \mathrm{ml}$ & ---- \\
\hline & $7.2 \pm 0.002$ & $16.53 \pm 0.001$ & $31.50 \pm 0.001$ & $49.18 \pm 0.003$ & $66.12 \pm 0.001$ & $81.12 \pm 0.002$ & ---- \\
\hline
\end{tabular}

*EOA: Ethanolic extract of Chromolaena odorata Linn;

**EOM: Methanolic extract of Chromolaena odorata Linn.

$\mathrm{OH}$ radical scavenging

The EOA and EOM extracts $(25-400 \mu \mathrm{g} / \mathrm{ml})$ significantly scavenged the hydroxyl radical generated by the EDTA/H2O2 system, when compared to that of ascorbic acid. The standard ascorbic acid (10-80 $\mu \mathrm{g} / \mathrm{ml})$, also showed scavenging effect (Table 3).

Table 2: Free radical scavenging activity of C. odorata Linn leaves extracts by hydroxyl radical scavenging

\begin{tabular}{|c|c|c|c|c|c|c|c|}
\hline \multirow[b]{2}{*}{ Drug } & \multicolumn{7}{|c|}{$\%$ Scavenging (Mean \pm SEM) of triplicates } \\
\hline & $5 \mu \mathrm{g} / \mathrm{ml}$ & $10 \mu \mathrm{g} / \mathrm{ml}$ & $20 \mu \mathrm{g} / \mathrm{ml}$ & $40 \mu \mathrm{g} / \mathrm{ml}$ & $80 \mu \mathrm{g} / \mathrm{ml}$ & $160 \mu \mathrm{g} / \mathrm{ml}$ & $300 \mu \mathrm{g} / \mathrm{ml}$ \\
\hline $\mathrm{EOA}^{*}$ & $51.46 \pm 0.002$ & $52.36 \pm 0.002$ & $52.08 \pm 0.001$ & $53.01 \pm 0.001$ & $53.23 \pm 0.002$ & $57.11 \pm 0.002$ & $59.89 \pm 0.002$ \\
\hline $\mathrm{EOM}^{* *}$ & $3.16 \pm 0.002$ & $8.06 \pm 0.001$ & $9.39 \pm 0.001$ & $12.06 \pm 0.001$ & $16.65 \pm 0.001$ & $24.05 \pm 0.002$ & $31.23 \pm 0.002$ \\
\hline \multirow[t]{2}{*}{ Vit C } & $0.1 \mu \mathrm{g} / \mathrm{ml}$ & $0.2 \mu \mathrm{g} / \mathrm{ml}$ & $0.4 \mu \mathrm{g} / \mathrm{ml}$ & $0.6 \mu \mathrm{g} / \mathrm{ml}$ & $0.8 \mu \mathrm{g} / \mathrm{ml}$ & $1 \mu \mathrm{g} / \mathrm{ml}$ & ---- \\
\hline & $7.2 \pm 0.002$ & $16.53 \pm 0.001$ & $31.50 \pm 0.001$ & $49.18 \pm 0.003$ & $66.12 \pm 0.001$ & $81.12 \pm 0.002$ & ---- \\
\hline
\end{tabular}

*EOA: Ethanolic extract of Chromolaena odorata Linn.

**EOM: Methanolic extract of Chromolaena odorata Linn.

$\mathrm{OH}$ radical scavenging

The EOA and EOM extracts $(25-400 \mu \mathrm{g} / \mathrm{ml})$ significantly scavenged the hydroxyl radical generated by the EDTA/H2O2 system, when compared to that of ascorbic acid. The standard ascorbic acid (10-80 $\mu \mathrm{g} / \mathrm{ml})$, also showed scavenging effect (Table 3). 
Table 3: Free radical scavenging activity of C. odorata Linn leaves extracts by hydroxyl radical scavenging

\begin{tabular}{cccccc} 
Drug & \multicolumn{5}{c}{$\%$ Scavenging (Mean \pm SEM) of triplicates } \\
& $\mathbf{2 5} \boldsymbol{\mu g} / \mathrm{ml}$ & $\mathbf{5 0} \boldsymbol{\mu g} / \mathrm{ml}$ & $\mathbf{1 0 0} \boldsymbol{\mu \mathrm { g } / \mathrm { ml }}$ & $\mathbf{2 0 0} \boldsymbol{\mu \mathrm { g }} / \mathrm{ml}$ & $\mathbf{4 0 0} \boldsymbol{\mu \mathrm { g } / \mathrm { ml }}$ \\
\hline EOA $^{*}$ & $52.46 \pm 0.002$ & $53.36 \pm 0.002$ & $52.08 \pm 0.001$ & $54.01 \pm 0.001$ & $55.23 \pm 0.002$ \\
EOM $^{* *}$ & $4.16 \pm 0.002$ & $9.06 \pm 0.001$ & $9.39 \pm 0.001$ & $13.06 \pm 0.001$ & $15.65 \pm 0.001$ \\
\hline Vit C & $10 \mu \mathrm{g} / \mathrm{ml}$ & $20 \mu \mathrm{g} / \mathrm{ml}$ & $40 \mu \mathrm{g} / \mathrm{ml}$ & $60 \mu \mathrm{g} / \mathrm{ml}$ & $80 \mu \mathrm{g} / \mathrm{ml}$ \\
& $7.2 \pm 0.002$ & $16.53 \pm 0.001$ & $31.50 \pm 0.001$ & $49.18 \pm 0.003$ & $66.12 \pm 0.001$
\end{tabular}

\section{Discussion}

C. odorata belongs to the family Asteraceae, is very much abundant and wide spread in nature. It has not attracted much attention so far. The medicinal values of plants lie in their component phytochemicals such as alkaloids, tannins, flavonoids and other phenolic compounds, which produce a definite physiological action on the human body. ${ }^{13} \mathrm{~A}$ systemic search for drug research in now considered to be a rational approach. Therefore in the present study an effort has been made to evaluate the antioxidant activity of the leaves of the above mentioned plant.

Earlier our in vitro study revealed that the ethanolic extract of C. odorata (L) possesses significant antigonorrhoeal activity. According to Chakraborty et al., the aqueous extracts of the leaves of C. odorata (L) possesses anti inflammatory activity ${ }^{14}$. Reactive oxygen species (ROS) generated endogenously or exogenously are associated with the various diseases such as atherosclerosis, diabetes, cancer, arthritis and aging process. Thus antioxidants can improve these disorders.

The free radical scavenging activity of the extracts was evaluated based on the ability to scavenge the DPPH. This assay is highly important to provide information about the reactivity of organic compounds with stable free radicals, because of the odd number of electrons. The result of the study reveals (table 1) that the ethanolic extract of the leaves of C. odorata (L) scavenged the free radicals by DPPH method. It shows a strong absorption band at $517 \mathrm{~nm}$ in visible spectrum (deep violet color). The bleaching of DPPH absorption indicates the capacity of the test drugs to scavenge the free radicals.

The result from table 2 exhibits that the ethanolic extract of the leaves of C. odorata (L) scavenged nitric oxide in vitro. It could be due to diverse phytochemicals including the phenolic compounds in the plant. Phenolic compounds have been implicated in antioxidant metabolism ${ }^{15}$ and the nitric oxide scavenging activity of flavonoids and phenolic compounds are known ${ }^{16,17}$.

Hydroxyl is one of the most damaging free radicals in the body and can be important mediator of damage to cell structures, nucleic acids, lipids and proteins ${ }^{18}$. The result from table 3 shows that the ethanolic extract of the leaves of C. odorata (L) has significant hydroxyl radical scavenging activity. It may be partly due to the presence of p-hydroxy benzoic (p-HBA). p-HBA has been found to be an important natural antioxidant. It is well established as an in vitro effective hydroxyl radical scavenger and has Trolox equivalent antioxidant activity (TEAC) ${ }^{19}$.

\section{Conclusion}

The study indicates that though C. odorata (L) has been considered as a notorious weed, its ethanolic and methanolic extract of leaves reveals significant antioxidant properties. The result of the present work appears to have a scientific basis and attests its use in traditional medicine. Therefore the future investigation should be directed towards elucidating more biological activities of the other plant parts collected from different geographical locations.

Conflict of interest: The authors declare that they have no conflict of interests. 


\section{References}

1. King RM, Robinson H. Studies in the Eupatorieae, The genus Chromolaena, Phytologia 1970; 20: 196-209.

2. Muniappan R. Weed management for developing countries, Plant Production and Protection Paper 120, Chromolaena odorata (L.) R.M. King and H. Robinson, In: Labrada R, Caseley JC, Parker C. Food and Agriculture Organization of the United Nations, Rome: 1994: p. 93-94.

3. Phan TT, Wang L, See P, Grayer RJ, Chan SY, LEE ST. Phenolic compounds of Chromolaena odorata protects cultured skin cells from oxidative damage. Implication for cutaneous wound healing. Biol and Pharma Bull 2001; 24:1373- 1379 .

4. Luximon-Ramma A, Bahorun T, Soobrattee MA and Aruoma OI, Antioxidant activities of phenolic, proanthocyanidin, and flavonoid components in extracts of Cassia fistula. J Agric Food Chem 2002; 50(18): 5042-5047.

5. HMG/N. Medicinal Plants of Nepal, Ministry of Forest and Soil Conservation: Department of Plant Resources. Kathmandu: 1993.

6. Rajbhandari RK. Medicinal Plants, In: Ethnobotany of Nepal, Ethnobotanical Society of Nepal, editors. Kathmandu: 2001:p. 98-34.

7. Yokozawa T, Chen CP, Dong E, Tanaka T, Nonaka GI, Nishioka I. Study on the inhibitory effect of tannins and flavonoids against the 1,1-diphenyl-2-picrylhydrazyl radical. Biochem Pharmacol 1998; 56: 213-22.

8. Conner EM, Grisham MB. Inflammation, free radicals and antioxidants. Nutrition 1996; 12: 274.

9. Comporti M. Three models of free radical induced cell injury. Chem biol interact 1989; 72: 1-56.

10. Gutteridge JMC. Age pigments and free radicals; Fluorescent lipid complexes formed by iron and copper containing proteins. Biochem Biophys Acta 1985; 834: 144.

11. Guyton KZ, Gorospe M, Holbrook NJ. Oxidative stress and the molecular biology of antioxidant defenses. New York: Cold Spring Harbour laboratory Press, 1997: 242-72.

12. Bolton S. In Pharmaceutical Statistics-Practical and Clinical Applications. New York: Marcel Dekker, 1997.

13. Hill AF. Economic Botany. A textbook of useful plants and plant products. New York: McGraw-Hill Book Company Inc, 1952: (2nd edn.)
14. Chakraborty KA, Roy H, Bastia S. Evaluation of antioxidant activity of the leaves of Eupatorium odoratum LINN. Int J Pharm Pharm Sci 2010; 4: 77-79.

15. Chung KT, Wong TY, Huang YW, Lin Y. Tanins and human Health: a review. Crit Rev Food Sci Nutr 1998; 38: 421-64.

16. Crozier A, Burns J, Aziz AA, Stewart AJ, Rabiasz HS, Jenkins GI, Edwards CA, Lean ME. Antioxidant flavonoids from fruits, vegetables and beverages; measurements and bioavailability. Biol Res 2000; 33: 79-88.

17. Jagetia SC, Rosk B, Balgia MS, Babu K. Evaluation of nitric oxide scavenging activity of certain herbal formulation in vitro. Phyto Res 2004; 18(7): 561-65.

18. Valko M, Leibfritz D, Moncola J, Cronin MTD, Mazura M, Telser J. Free radicals and antioxidants in normal physiological functions and human disease. IJBCB 2007; 39: 44-84.

19. Rice-Evans CA, Miller NJ, Paganga G. Antioxidant properties of phenolic compounds. Trends in Plant Sci 1997; 2: 152-59. 